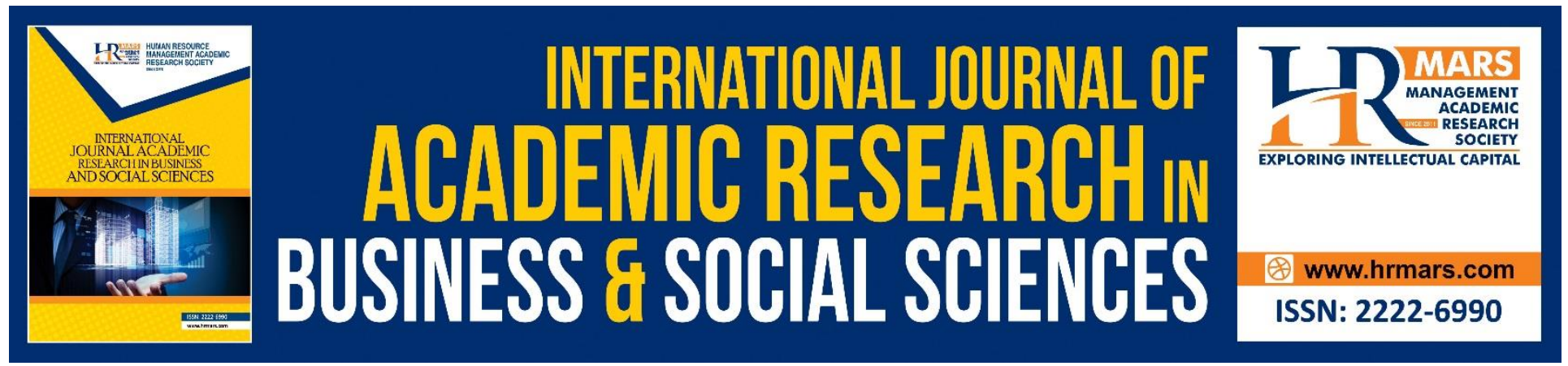

\title{
Premature Babies: Contributing Factors, Problems and Need for Milk Bank
}

Normadiah Daud, Nur Hidayah Ashar, Rahimah Embong, Nadhirah Nordin, Siti Khatijah Ismail, Hasanuldin Mohamad, Mohamed Fathy Mohamed Abdelgelil

To Link this Article: http://dx.doi.org/10.6007/IJARBSS/v8-i10/4738

DOI: $10.6007 /$ IJARBSS/v8-i10/4738

Received: 09 Sept 2018, Revised: 13 Oct 2018, Accepted: 24 Oct 2018

Published Online: 31 October 2018

In-Text Citation: (Daud et al., 2018)

To Cite this Article: Daud, N., Ashar, N. H., Embong, R., Nordin, N., Ismail, S. K., Mohamad, H., \& Abdelgelil, M. F. M. (2018). Premature Babies: Contributing Factors, Problems and Need for Milk Bank. International Journal of Academic Research in Business and Social Sciences, 8(10), 330-339.

Copyright: (C) 2018 The Author(s)

Published by Human Resource Management Academic Research Society (www.hrmars.com)

This article is published under the Creative Commons Attribution (CC BY 4.0) license. Anyone may reproduce, distribute, translate and create derivative works of this article (for both commercial and non-commercial purposes), subject to full attribution to the original publication and authors. The full terms of this license may be seen at: http://creativecommons.org/licences/by/4.0/legalcode

Vol. 8, No. 10, 2018, Pg. 330 - 339

Full Terms \& Conditions of access and use can be found at http://hrmars.com/index.php/pages/detail/publication-ethics 


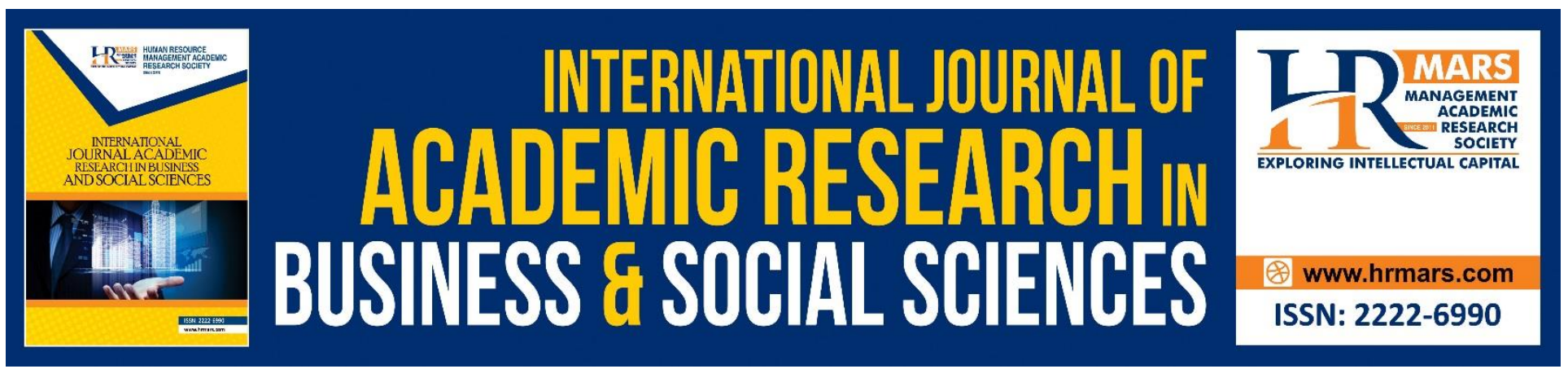

\title{
Premature Babies: Contributing Factors, Problems and Need for Milk Bank
}

\author{
Normadiah Daud, Nur Hidayah Ashar, Rahimah Embong, Nadhirah \\ Nordin, Siti Khatijah Ismail, Hasanuldin Mohamad, Mohamed Fathy \\ Mohamed Abdelgelil
}

Faculty of Islamic Contemporary Studies, Universiti Sultan Zainal Abidin, Malaysia

\begin{abstract}
This article aims to discuss the critical need of premature babies for the milk bank in the Muslim society. It is a matter of fact that the increment in numbers of premature births annually is quite significant based on the statistics about it since year 2005 up to the present. The issue of premature births should be concerned by the Ministry of Health and community because of the high risk of death. Premature babies are categorized as high risk if not getting breast milk and this could bring harm to them. Therefore, milk bank should be developed to save their lives. This is because it gives betterment (maslahah) more than harm (mafsadah) for Muslims. This study was qualitative and used content analysis method. The data were obtained from primary and secondary relevant sources. This article elucidates the definition of premature infants, statistical information of premature births, contributing factors to the premature birth, diseases that are susceptible to them and lastly their need for breastmilk that lead to the development of milk bank. All parties should put mutual efforts in ensuring the milk bank to be successfully implemented.
\end{abstract}

Keywords: Premature infant, Milk Bank, Breastmilk, Premature Birth

\section{Introduction}

Premature baby refers to a newborn baby or an infant with Low Birth Weight (LBW). Conventionally, definition of premature is referring to the birth prior to 37-week pregnancy. In medical terms and according to WHO, premature infants are the babies born before the 37th week of pregnancy (Turner-Maffei et al., 2014). According to Malaysian Ministry of Health, most infants are expected to be born within 40 weeks of gestation. Thus, the newborn baby is matured if he or she is born between 37 to 42 weeks of gestation. If a baby is born prior to 37-week of gestation, it is regarded to be premature. There is a term of late premature if the baby is born between the period of gestation of 34 weeks and 0 day to 36 weeks and 6 days. Hence, the well-matured newborn baby is born between the 37 weeks and 0 day to 41 weeks and 6 days (Musa, 2001). 
There are sub-categories of premature birth based on the period of pregnancy which are premature (less than 28 weeks), very premature (28 to 32 weeks) and medium to late premature (32 to 37 weeks). In addition, the definition of Low Birth Weight (LBW) infant is a new born baby with less than $2500 \mathrm{~g}$ body weight. Meanwhile, newborn babies with a weight less than $1500 \mathrm{~g}$ are called Very Low Birth Weight (VLBW). Next, newborn baby with less than $1000 \mathrm{~g}$ is termed as Extreme Low Birth Weight (ELBW) (Musa, 2001). Therefore, premature infants need to get intensive care because they were born prior to the full period of gestation. Therefore, there is a critical need for the development of milk bank.

\section{The Increase of Premature Birth Rate}

Relating to the issue of milk bank, the report released by the Malaysian National Neonatal Registry (MNNR) on census that involved the participation about 30 Neonatal Intensive Care Units (NICU) at several hospitals throughout Malaysia which are registered under MNNR. MNNR is one of the neonatal registration portals established to study and record the number of babies warded into the NICUs for one year. The selection criteria for premature infants are according to their weight of the same or below 1500g since year 2005 to 2008 and in 2010. It is found that the number of premature births has been increasing year by year. In 2005, MNNR reported that there were 226,878 births in 27 hospitals who took part and about 2063 were stillbirth while 224,815 were alive. About 32.2\% of births are premature infants under 32 weeks of gestational age and $37.2 \%$ are birth weight $1500 \mathrm{~g}$ and below. After two years, the number of births increased to 249,468 births in 32 hospitals where 2081 were stillbirth and 247,387 were alive. In addition, it reported the number of babies who were at stage three at NICUs was 10835 babies. The number of premature babies recorded below 32 weeks of gestational age is 3203 babies and 3651 babies were born with weight 1500g and below.

In 2008, 258,635 newborn babies were reported by MNNR in 32 participating hospitals in which 2198 were stillbirths and 256,437 were live births. A total of 11,219 births were recorded at stage III of the NICUs. A total of 3348 premature babies under 32 weeks of pregnancy and 3699 newborn babies with weight of $1500 \mathrm{~g}$ and below were reported during that year. In 2010, MNNR reported a total of 269,012 baby births in 34 participating hospitals. Out of this number, 11,685 babies were at stage III of the NICUs. This year, it has recorded 3320 premature babies under 32 weeks of gestation and 3699 babies were born with weight $1500 \mathrm{~g}$ and below. Based on birth statistics, it can be analyzed hat the number of premature births is increasing from year to year. The Figure 1 is the statistics of the number of babies from 2005 to 2008 and in 2010. 
INTERNATIONAL JOURNAL OF ACADEMIC RESEARCH IN BUSINESS AND SOCIAL SCIENCES Vol. 8, No. 10, Oct. 2018, E-ISSN: 2222-6990 @ 2018 HRMARS

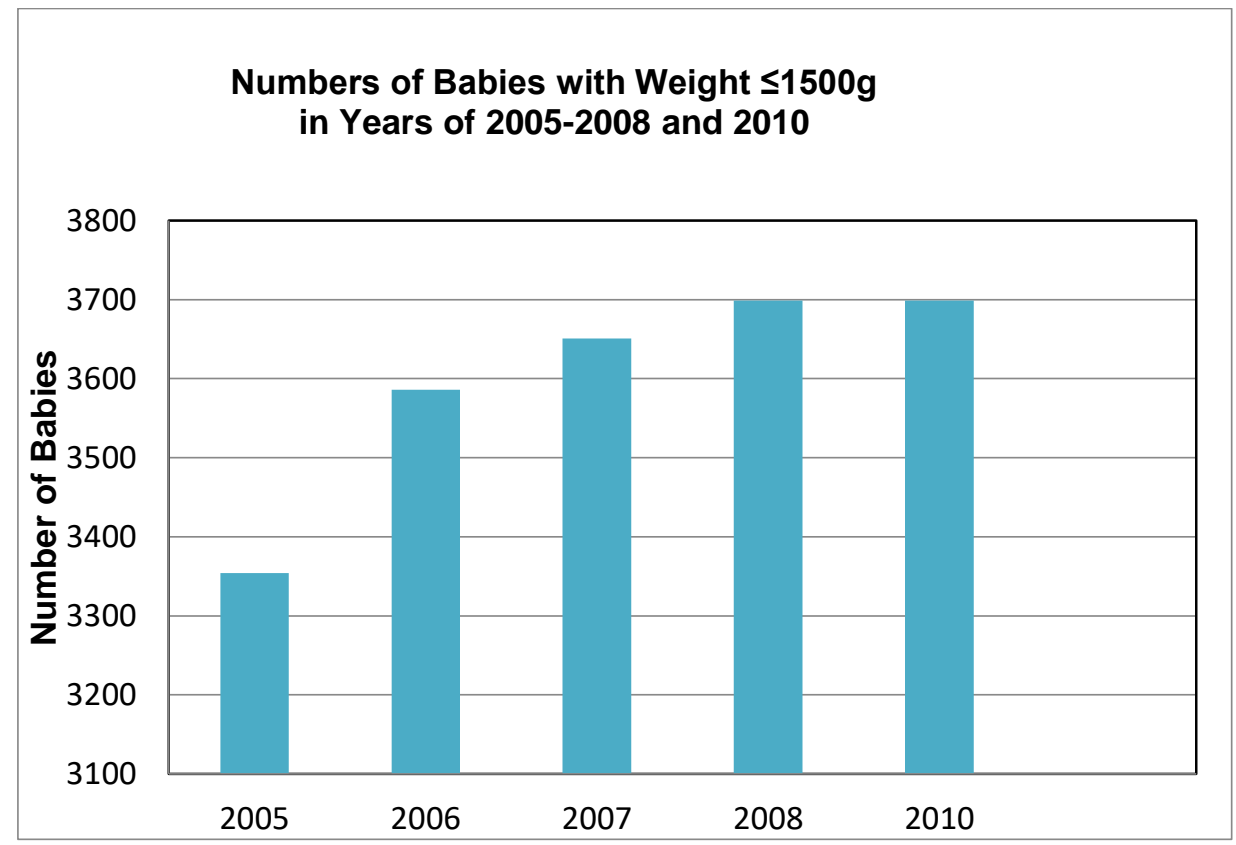

Table 1.1: Statistic of Premature Births

Years of 2005-2008 and 2010

In sum, the statistics apparently shows, the total number of premature birth (1500g and below) is constantly increasing from year 2005 to 2010. So that, the study predicts the number of premature babies will be continuously increasing in the future.

\section{Contributing Factors of Premature Births}

Referring to the age of the baby born under 37 weeks of gestation that is three weeks earlier than the complete birth of 40 weeks. There are several factors that are contributing to the rise of premature births. Among them, according to a report released by the UKM News Portal on June 4, 2015 , studies showed that about $5 \%$ to $18 \%$ annually, nearly 15 million out of infants born worldwide were premature. This percentage is likely increasing significantly due to changes in the community lifestyle nowadays. Therefore, the factors of premature births are mothers having diseases, overaged mothers, bacterial infections in mother's womb and the presence of bacteria in mother's urine. These factors may cause the premature babies at risk (Asmahanim, 2015). According to the Malaysian Pediatric Association, the prevalence of premature births is caused by high blood pressure, diabetes, bleeding, abdominal cavity, amniotic fluid, bacterial infections and others. In addition, factors in the fetus such as twin birth, inadequate fetal growth can cause the baby to be born prematurely. Additionally, low socio-economic and under-prenatal care contributed to this problem. Based on statistics it is found that approximately $50 \%$ of the premature birth is due to unknown cause. This may be due to the emotional stress of pregnant mother or the problem of bacterial infections in the birth canal (Musa, 2001). Another condition is latrogenic preterm birth that is triggered for medical reasons such as mothers with serious preeclampsia that is hypertension or 
INTERNATIONAL JOURNAL OF ACADEMIC RESEARCH IN BUSINESS AND SOCIAL SCIENCES

Vol. 8, No. 10, Oct. 2018, E-ISSN: 2222-6990 ㄷ 2018 HRMARS

eclampsia, so that, the baby should to be delivered earlier to save the mother's life (Ward \& Hisley, 2016).

\section{Mothers Having Diseases}

Among the factors that cause diseases to the mother are due to maternal health problems such as mothers with high blood pressure and chronic diabetes, suffering from thyroid gland problem, bacterial infections in the amniotic and vaginal or having fibroids. These are the factors that cause high-risk mothers with premature births (Women's Health Portal, 2018). According to the MyHEALTH portal, the main reason of premature birth as yet to be identified, However, about $20 \%$ of cases because of the doctor had to take out the baby early prior to induction time. This often happens if the mother having chronic diseases that will only cure if the baby is born such as a mother with high blood pressure, diabetes and Intra Uterine Growth Retardation (IUGR) (Portal MyHEALTH, 2017).

Every pregnant woman has potential to have high blood pressure with a percentage of $10 \%$ to $15 \%$ where it can be categorized as quite high. In medical aspect, women will get such disease regardless their status of the country whether developing or not. Obstetric and Gynecologist from Kelana Jaya Medical Center, Dr. S. Silvam asserted that high blood pressure in pregnant women usually occurs at 20 weeks and more gestational age. However, if it occurs earlier than this period, the patient's screening should be done to check up if there are other kidney-related diseases or family medical history who have a high blood pressure (Fazrina, 2008). According to him, pregnant women is getting high blood pressure due to changes in the placenta developmental process that is vital during the pregnancy process. There are many blood vessels in the placenta. Blood pressure occurs when the blood vessels in the arteries namely spiral arteries are not developing but shrinking and causes the blood circulation of the mother's body does not flow perfectly. In addition, normal blood pressure for non-pregnant woman is 140 to 90 while pregnant woman is 110 to 70 . If more than 110 is considered as having high blood pressure (Fazrina, 2008).

\section{Preeclampsia}

Preeclampsia is a condition caused by pregnancy, and it occurs in the second trimester of pregnancy usually after 20 weeks of pregnancy. Pre-eclampsia is associated with high blood pressure, sudden swelling and sudden increase in weight due to the accumulation of water in the body and the presence of protein in the urine. Preeclampsia causes reduction in blood flow to the placenta that could bring harm the baby in the womb. The growth of baby becomes retarded due to insufficiency of the quantity of oxygen and nutrients that reach the baby (Izzat, 2016). This condition could cause the baby suddenly dying in the womb. Preeclampsia pregnancy will be monitored from time to time to detect babies who will get this complication so that immediate action can be taken to save her life. Although it is rare that only 1 case in 4000 pregnancies, eclampsia gives serious complications to both mother and baby, as well as could lead to death (Izzat, 2016). 


\section{Gestational Diabetes}

Another health problem is a pregnant mother with diabetes known as Gestational Diabetes. This is due to the resistance of insulin that is a hormone produced by the human body to regulate blood sugar levels, in order to meet the needs of pregnancy. As a result, sugar level in the blood will be increasing. Typically, Gestational diabetes occurs in the middle or at the end of the pregnancy (Izzat, 2016). Gestational Diabetes frequently occurs among 10 out of 100 pregnant women will be suffering from this disease. The contributing factors for high risk of getting diabetes during pregnancy are having Body Mass Index (BMI) about 30 or more, history of delivering a large baby with over $4 \mathrm{~kg}$ or more, history of diabetes mellitus during previous pregnancy or the record of parents and siblings who also have such illness (Izzat, 2016). Most mothers who have diabetes during pregnancy have no problems during the pregnancy process, but there are a handful of cases that bring serious problems to mothers and babies, especially if this disease is not diagnosed earlier and not treated optimally. The ability to detect this diabetes during pregnancy earlier and optimal control of the sugar level can reduce the risks and related complications (Izzat, 2016).

\section{Twin}

Another factor is the complication of pregnancy caused by medical assistance due to twin pregnancies. This is because the cervical canal is not large enough to place two or more babies in the womb. The frequency of this complications ranged from $15 \%$ to $50 \%$ among newborn babies with weight of less than $1,500 \mathrm{~g}$, but the cases may vary with a considerable range depending on the treatment center and the average in pregnancy of premature babies that can be saved (Asmahanim, 2015). Thus, the significant factors of premature births are mothers with high blood pressure, diabetes and complications in the womb that cause the underweight baby.

\section{Advanced Maternal Age}

Another contributing factor of premature birth is the pregnant woman's age weather too old or too young. The problem faced by the baby is also depending on the age of pregnancy. Thus, the shorter duration of the baby in the mother's womb, the risk of having health problem is higher (Asmahanim, 2015). Notwithstanding most older mothers can conceive and able to deliver safely, they have higher risk of getting health problems such as diabetes and high blood pressure. These problems can affect their health, pregnancy and delivery. Even miscarriage and pregnancy outside the womb (ectopic pregnancy) are more common among older women. In addition to giving problems to a mother, it is also for a baby whose risk to be died in the womb if the mother's age is over 40 years. This risk is highest around the 41st week of pregnancy. However, the rate is still low at 10 death cases per 1,000 births. Therefore, a mother who conceives at older age are likely to cause premature birth. Thus, doctors do not encourage older mothers to get pregnancy because their age could be one of contributing factor to this case. In sum, the over-aged mother is not recommended for pregnancy.

\section{Bacterial Infection in Mother's Womb}

The premature birth is also caused by the effects of infections in the mother's womb where germs and inflammatory processes initiate hormone secretion as well as other factors that can trigger contraction in the uterus. This causes pregnant women will feel painful to give birth when the 
membranes rupture before the due date. In view of this, the early born babies because the cervical environment is no longer suitable for the fetus to survive due to the spread of infectious germs (Asmahanim, 2015). There are several conditions which are closely related to premature birth. The first condition is reproductive canal infected by the bacterium Treponema pallidum which causes syphilis disease. Untreated primary or secondary syphilis as a contributing factor to this premature delivery rate is approximately $50 \%$. The second condition is the gonococcal infection that causes the gonorrhea. The third is infection of bacterial vaginosis (BV) when normal vaginal flora is replaced with atypical bacteria (Ward \& Hisley, 2016). The next condition is the infection of amnion fluid but the amniotic membrane still remain. The space of amniotic membrane that typically sterile or germ-free could be infected and will be reproducing various types of microorganisms. This will cause earlier uterine contraction earlier. Thus, bacterial infections in the womb are one of the factors that cause premature birth.

\section{The presence of Bacteria in Mother's Urine}

In addition, bacterial infections can occur in non-reproductive as well as reproductive canals. Infection on non-reproductive canals is asymptomatic bacteriuria containing bacteria, but patients do not show any symptoms of infection. This condition is closely related to premature birth. Untreated acute pyelonephritis is a type of bacterial infection in the kidneys. The risk of premature birth for mothers who get this infection is about $30 \%$ compared to pneumonia is about $25 \%$ (Ward \& Hisley, 2016). The presence of certain bacteria in the urine will increase the possibility of preterm labour although pregnant women may have no signs of infection. That is why a doctor will carry out urine tests to detect bacteria in the early stages of pregnancy. Treating infections reduces the risk of premature birth. Furthermore, the vagina also contains bacteria that are believed to increase the possibility of premature delivery.

\section{Illness in Premature Babies}

Premature babies need special treatment compared to normal-born babies. During the treatment period, the baby's health status will be monitored continuously in the incubator. Most premature babies will be kept in the Neonatal Intensive Care Unit (NICU). This is because, premature infants are easily infected with various high-risk diseases.

\section{Jaundice}

The most common illness among premature babies is jaundice. It is caused by an excess of bilirubin produced by red blood cell breakdown. This bilirubin causes the baby's skin and white membranes to be yellow. Although this illness is common during infancy, but if the level of jaundice is too high, it can cause damage to the baby's brain or the hearing impairment (Brodsky \& Ouellette, 2008).

\section{Apnea}

Premature baby is possible to experience apnea that is a condition of the baby stops breathing. At that moment, the baby's heart rate is slowing down as well as the baby may look pale and blue. This frequently happens to a newborn baby less than 30 weeks. If this apnea problem occurs frequently, the baby needs medication to stimulate the respiratory system well (Green-Hernandez et al., 2001). 
INTERNATIONAL JOURNAL OF ACADEMIC RESEARCH IN BUSINESS AND SOCIAL SCIENCES

Vol. 8, No. 10, Oct. 2018, E-ISSN: 2222-6990 @ 2018 HRMARS

\section{Anemia}

Most premature babies are suffering from anemia sue to blood deficiency. This disease may prevent the growth of the baby. If the level of anemia is serious, the baby may face heart failure and problems with her respiratory system known as Respiratory Distress Syndrome. (Guha, 2005).

\section{Respiratory Distress Syndrome}

Respiratory Distress Syndrome (RDS) is a quite common condition that causes the baby to have difficulty breathing due to her immature lungs. However, this problem can be overcome by using a type of drug that acts on the opening of the lungs known as surfactant. It allows the premature baby lungs to function better. If this breathing problem is too serious, the baby may need respiratory assistance through the respiratory tract. The use of synthetic surfactants will reduce the complications of respiratory problems (Benson \& Haith, 2009).

\section{Problems with Baby's Immune System}

The most worrying problem among premature babies is related to their immune system. Premature babies are susceptible to infectious diseases because they are not able to fight illnesses as full-term babies. The infection may occur prior or post birth. One of the ways to overcome this problem is by practicing handwashing in the right way (Bradford, 2003).

\section{Patent Ductus Arteriosus}

Premature babies are easily getting the risk of Patent Ductus Arteriosus (PDA). PDA is an extra blood vessel that connects the pulmonary artery and the aorta. Premature babies with PDA problems depend on the PDA size that can cause the baby to have heart failure problem. There are medications that can diminish the bloodstream. However, if the medication is unsuccessful, it can be resolved through surgery (Obladen \& Koehne, 2005).

\section{Retinopathy of Prematurity}

The risk of premature babies is the retinal problem of Retinopathy of Prematurity (ROP). Premature infants have a relatively sensitive retina. Her retina may be injured that finally can lead to serious eye problems (Joussen et al., 2007).

\section{Conclusions}

In sum, based on previous studies done by physician doctors regarding the risk of premature birth that could be saved only 50\%. Looking at the growing number of premature babies, as well as the inability of mothers to breastfeed their own babies due to certain problems, this will lead to difficulties in premature babies to get breast milk and eventually bring harm to them. This is because the breast milk is necessary for the survival of premature babies. They need to receive good nutrition, so they can grow at the similar condition with the baby in the womb (Poindexter \& Ehrenkranz, 2015). The choice of breast milk to premature babies due to its nature easier to digest as well as the baby could take it through the tubes without much trouble compared to infant formula. Baby's kidneys are also capable to process breast milk easier compared to formula milk. Hence, breastmilk is the best nutrition for premature babies to fight against disease infections and help the immature intestines 
INTERNATIONAL JOURNAL OF ACADEMIC RESEARCH IN BUSINESS AND SOCIAL SCIENCES Vol. 8, No. 10, Oct. 2018, E-ISSN: 2222-6990 @ 2018 HRMARS

to get adequate nutrients. Therefore, the development of milk bank that supplies enough breast milk is necessary to save their lives. However, the development of this milk bank needs to be studied thoroughly so that its implementation will be meet the need of Muslim community in Malaysia at this contemporary era.

\section{Acknowledgement}

We express our deepest gratitude to the Centre for Research Management, Innovation \& Commercialization (RMIC) as well as Faculty of Islamic Contemporary Studies, Universiti Sultan Zainal Abidin, Terengganu, Malaysia for supporting the publication of this article.

\section{Corresponding Author}

Normadiah Daud, is Associate Professor and Deputy Dean of Academic \& Graduates at Faculty of Islamic Contemporary Studies, Universiti Sultan Zainal Abidin Malaysia.

Email: normadiah@unisza.edu.my

\section{References}

Asmahanim, A. (4 June 2015). Bilangan Bayi Dilahirkan Pramatang Meningkat Kerana Perubahan Gaya Hidup Semasa. Retrieved from http://www.ukm.my/news/Latest News/bilangan-bayidilahirkan-pramatang-meningkat-kerana-perubahan-gaya-hidup-semasa/

Benson, J.B. \& Haith, M.M. (2009). Diseases and Disorders in Infancy and Early Childhood. (Ed.1.) USA: Elsevier Publications.

Bradford, N. (2003). Your Premature Baby: The First Five Years. Toronto: Firefly Books.

Brodsky, M.D.D. \& Ouellette, M.A. (2008). Primary Care of the Premature Infant. MS APRN IBCLC. United States: Elsevier Inc.

Fazrina, N. K. (2008). Ibu Hamil Waspada Darah Tinggi. Online Utusan Portal. Health Section: Retrieved from http://ww1.utusan.com.my/utusan/info.asp?y=2008\&dt=0603\&sec= kesihatan\&pg=kn 03.htm

Green-Hernandez, C., Singleton, J.K. \& Aronzon, D.Z. (2001). Primary Care Pediatrics. United States: Lippincott Williams \& Wilkins.

Guha, D.K. (2005). Guha's Neonatology Principles \& Practice. New Delhi: Jaypee Brothers Medical Publishers (P) LTD.

Izzat, M. (2016). Tekanan Darah Tinggi ketika Hamil: Pra-Eklampsia. [Web log post]. Retrieved from The Malaysian Medical Gazette: http://www.mmgazette.com/tekanan-darah-tinggi-ketikahamil-pra-eklampsia-dr-muhammad-izzat/

Joussen, A.M., Gardner, T.W., Kirchhof, B. \& Ryan, S.J. (2007). Retinal Vascular Disease. New York: Springer Medizin Verlag Heidelberg.

Musa, M.N. (4 September 2001). Penjagaan Bayi yang Pramatang dan Kurang Berat Badan (Low Birth Weight). [Web log post]. Retrieved from portal Persatuan Pediatrik Malaysia (MPA): http://www.mpaweb.org.my/article.php?aid=103.

Obladen, M. \& Koehne, P. (2005). Interventions for Persisting Ductus Arteriosus in the Preterm Infant. New York: Springer Medizin Verlag Heidelberg.

Poindexter, B.B. \& Ehrenkranz, R.A. (2015). Nutrient Requirements and Provision of Nutritional 
INTERNATIONAL JOURNAL OF ACADEMIC RESEARCH IN BUSINESS AND SOCIAL SCIENCES

Vol. 8, No. 10, Oct. 2018, E-ISSN: 2222-6990 ㄷ 2018 HRMARS

Support in The Premature Neonate (10 ${ }^{\text {th }}$ ed.). Philadelphia: Elsevier Saunders.

Portal MyHEALTH. (2017). Portal Rasmi MyHEALTH Kementerian Kesihatan Malaysia. Retrieved from http://www.myhealth.gov.my/bayi-pramatang/

Report of the Malaysian National Neonatal Registry 2005. Retrieved from http://www.acrm.org.my/mnnr/documents/nnrReport2005.pdf.

Report of the Malaysian National Neonatal Registry 2006. Retrieved from http://www.acrm.org.my/mnnr/documents/nnrReport2006.pdf.

Report of the Malaysian National Neonatal Registry 2007. Retrieved from http://www.acrm.org.my/mnnr/documents/nnrReport2007.pdf.

Report of the Malaysian National Neonatal Registry 2008. Retrieved from http://www.acrm.org.my/mnnr/documents/nnrReport2008.pdf.

Report of the Malaysian National Neonatal Registry 2010. Retrieved from http://www.acrm.org.my/mnnr/documents/nnrReport2010.pdf.

Turner-Maffei, Cadwell, K. \& Cindy (2014). Breastfeeding A-Z. America: Jones \& Bartlett Learning

Ward, S. \& Hisley, S. (2016). Maternal-Child Nursing Care Optimizing Outcomes for Mothers, Children \& Families ( $2^{\text {nd }}$ ed.). America: F.A. Davis Company.

Women's Health Portal. (2018, June 6). Pregnancy complications. [Web log post]. Retrieved from https://www.womenshealth.gov/pregnancy/youre-pregnant-now-what/pregnancycomplications 